\title{
A newly established round goby (Neogobius melanostomus) population in the upper stretch of the river Elbe
}

\author{
K. Roche ${ }^{(1), \star}$, M. Janáč ${ }^{(1)}$, L. Šlapanský( ${ }^{(1)}$, L. Mik( ${ }^{(1)}$, L. Kopeček ${ }^{(1)}$, P. Jurajda ${ }^{(1)}$ \\ Received October 9, 2015 \\ Revised October 22, 2015 \\ Accepted October 26, 2015
}

Key-words: Gobiidae, species introduction, non-native species, population expansion, ship-mediated transport

\section{ABSTRACT}

The invasive round goby (Neogobius melanostomus, Pallas, 1814) has increased its European range dramatically over recent decades, with international shipping suspected as the main vector. Here, we provide the first population and morphological data for a newly established round goby population in the upper Elbe (Ústí nad Labem, Czech Republic). Surveys in 2013 along the same stretch found no evidence of gobies, indicating introduction within the past two years. Analysis of morphological similarity confirms the most likely source as the recently established population in the tidal Elbe near the port of Hamburg. Due to the species' restricted range ( $<15 \mathrm{~km}$; with density localised on Ústí nad Labem port), distance from proposed source $(600 \mathrm{~km}$; no reports from the intervening stretch) and the speed with which this distance was crossed (less than three years), we suggest port-to-port transfer as the most likely vector route. Our data highlight the speed with which this species has been able to colonise most watersheds in Europe via establishment of widelyseparated populations through port-to-port transfer and rapid inter-site connection through downstream drift and natural migration.

\section{RÉSUMÉ}

La population de gobie à taches noires nouvellement implantée (Neogobius melanostomus) dans un bief amont du fleuve Elbe

Mots-clés : Gobiidae, introduction d'espèce, espèce non indigène, expansion de population,
Le gobie à taches noires invasif (Neogobius melanostomus, Pallas, 1814) a augmenté son aire de répartition européenne de façon spectaculaire au cours des dernières décennies, le transport maritime international étant soupçonné d'être le principal vecteur. Ici, nous fournissons les premières données populationnelles et morphologiques sur ce gobie à taches noires nouvellement implanté dans l'Elbe supérieure (Ústí nad Labem, République tchèque). Des sondages en 2013 le long du même tronçon n'ont trouvé aucune preuve de gobies, impliquant que l'introduction date des deux dernières années. L'analyse de similitude morphologique confirme que la source la plus probable de la population récemment établie est dans l'estuaire de l'Elbe près du port de Hambourg. En raison de l'extension

(1) Institute of Vertebrate Biology, Academy of Sciences of the Czech Republic, v.v.i., Květná 8, 60365, Brno, 
1 transfert par bateau locale restreinte de l'espèce ( $<15 \mathrm{~km}$; avec la densité localisée près du port Ústí nad Labem), et de la distance de la source proposée $(600 \mathrm{~km}$, pas de données sur le tronçon intermédiaire) et la rapidité avec laquelle cette distance a été franchie (moins de trois ans), nous suggérons un transfert de port à port comme vecteur de transport le plus probable. Nos données mettent en évidence la rapidité avec laquelle cette espèce a été capable de coloniser la plupart des bassins hydrographiques en Europe par la création de populations largement séparées par le transfert de port à port et la connexion rapide inter-site par la dérive vers l'aval et la migration naturelle.

\section{INTRODUCTION}

The round goby (Neogobius melanostomus, Pallas, 1814) is one of a number of PontoCaspian Gobiids that have expanded their ranges over recent decades (see review in Roche et al., 2013). A native of the Black, Caspian and Azov Seas and their tributaries (Miller, 2004), the species became established in several major European watersheds around the 1990s, including those of the Danube (Jurajda et al., 2005; Painter and Seifert, 2006; Wiesner, 2005), Rhine (Borcherding et al., 2011; Kalchhauser et al., 2013; Van Beek, 2006) and the Vistula and Oder (Grabowska et al., 2010). They have even been introduced into the Laurentian Great Lakes of North America (Jude et al., 1992). It is now generally accepted that initial introductions have been through international shipping at major ports (Wiesner, 2005) through accidental transport of juveniles/eggs in ballast water or as eggs attached to the ship's hull (Ahnelt et al., 1998; Hayden and Miner 2009), followed by natural spreading from the point(s) of introduction (Roche et al., 2013). Movement may also be assisted through introduction by anglers as bait or by transport of eggs/juveniles on equipment (Kornis et al., 2012). In this way, widely separated introduction points have quickly been joined and large stretches of navigable river colonised. This has been supported in many cases by the ubiquitous presence of rip-rap banks, a preferred habitat of this species (Jurajda et al., 2005; Ray and Corkum, 2001), along Europe's navigable rivers. Natural colonisation, e.g. along non-navigable tributaries, tends to be slower (Schomaker and Wolter, 2014). The round goby has also been introduced into brackish and marine waters in Europe; indeed, the first reported introduction outside of its native area was into the Gulf of Gdansk (Southern Baltic Sea) in 1990 (Skóra and Stolarski, 1993). Since then, they have spread along the Baltic Sea coast (Michalek et al., 2012; Sapota and Skóra, 2005), with the western dispersal route reaching the coastal waters of the Jutland peninsula. Further expansion of this branch, together with eastward spread through canals connecting North Sea Basin rivers (Brunken et al., 2012; van Beek, 2006), was the probable source of round goby colonisation of the lower River Elbe (Hempel and Thiel, 2013).

Round gobies were first reported on the River Elbe on the tidal stretch at Hamburg (Germany; $53^{\circ} 31^{\prime} 28^{\prime \prime} \mathrm{N}, 9^{\circ} 59^{\prime} 11^{\prime \prime} \mathrm{E}$; Figure 1) in 2008 , having been caught by a commercial fisherman (Hempel and Thiel, 2013). Between 2011 and 2013, the species was being caught relatively frequently by anglers around Hamburg. Despite the presence of a large weir separating the freshwater upstream Elbe and the tidally influenced Elbe "estuary", one specimen has been caught further upstream, near the town of Geesthacht $\left(53^{\circ} 43^{\prime} 58^{\prime \prime} \mathrm{N}, 10^{\circ} 37^{\prime} 79^{\prime \prime} \mathrm{E} ; \mathrm{r}\right.$. km 936), $34 \mathrm{~km}$ southeast of Hamburg in 2012 (Hempel and Thiel, 2013). No fish have been reported above this point to date.

On the 4th August 2015, a round goby was caught for the first time in the upper Elbe at Svádov (Czech Republic), near the city of Ústí nad Labem $\left(50^{\circ} 39^{\prime} 38^{\prime \prime} \mathrm{N}, 1^{\circ} 031^{\prime \prime} 56^{\prime \prime} \mathrm{E}\right.$; Figure 1), 603 r. km upstream of Geesthacht, during an ecotoxicological examination by the Czech Angling Union (T. Kava, Czech Angling Union, Pers. Comm.). Up to that date, there had been no report of gobies above Geesthacht. On the 17th August, a fish was accidentally caught during sampling of zoobenthos (Buřič et al., 2015) and a further individual was reported by an angler close to the previous site (village of Povrly; $50^{\circ} 40^{\prime} 23.3^{\prime \prime} \mathrm{N}, 14^{\circ} 09^{\prime} 38.3^{\prime \prime} \mathrm{E}$ ) 


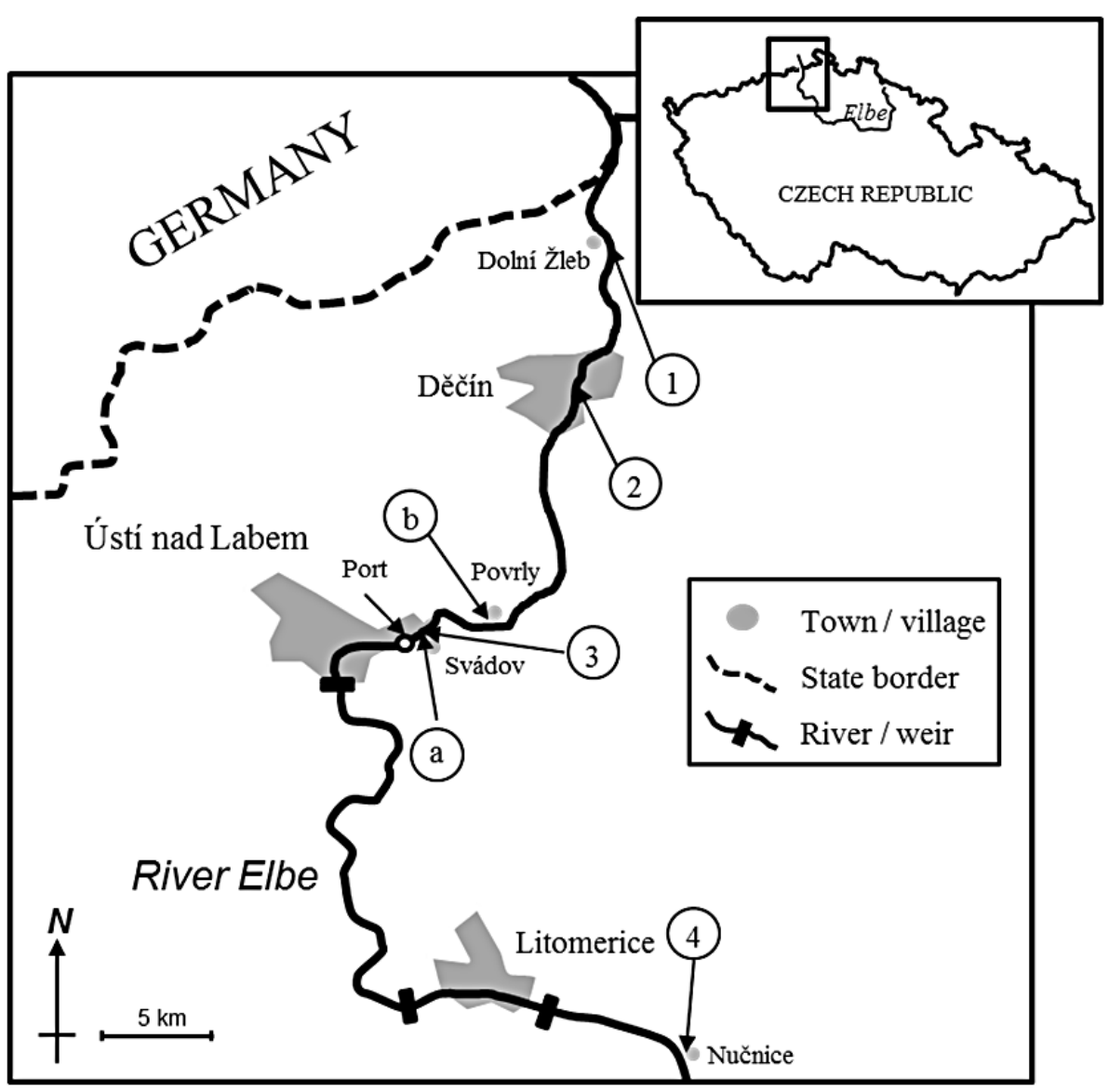

\section{Figure 1}

Map of the upper Elbe illustrating: a) first finding of round goby (4.8.2015), b) second individual caught (20.8.2015), 1) the Dolní Žleb sampling site, 2) the Děčín sampling site, 3) the Svádov sampling site, and 4) the Nučnice sampling site (1-4 all 26.8.2015); see Table I for coordinates.

on the 20th August (Skalický in litt.). Very soon after (see below), while undertaking mandatory ichthyological monitoring of the upper Elbe under the EU Water Framework Directive, members of the Institute of Vertebrate Biology, Czech Academy of Sciences, caught multiple specimens at several locations along the river. An identical survey by the Academy and the Angling Union in 2013 (Jurajda et al., 2013; unpublished report) found no goby presence along the same stretch, suggesting introduction sometime within the last two years.

Here, we provide the first data on population characteristics (size, sex ratio, proportion of juveniles) for this new population, along with morphometric measurements and a discussion on the possible source of the population. In addition, we provide data on the native ichthyofauna, thus providing background data for assessing any future impact of this non-native species on local fish populations.

\section{METHODS}

Fish sampling was conducted at four sites on the River Elbe between Dolní Žleb (5 km upstream of the Czech/German border) and Nučnice on the 26th August 2015 (Figure 1; see Table I for coordinates). The riverbank throughout this stretch has been modified and stabilised with $10-50 \mathrm{~cm}$ stony rip-rap. The river bottom in the section from Dolní Žleb to Svádov has a natural stony substrate and, during periods of very low discharge (as during this sampling period), some parts of the bank consist of sand-gravel beaches. Aquatic vegetation was absent throughout the stretch. The Nučnice site lies above a weir and water flow is much 
reduced. As a result, the river bottom is covered with mud and nearshore aquatic vegetation is commonly present.

Fish were caught along the river bank (depth not exceeding $80 \mathrm{~cm}$, mean sampled width ca. $1.2 \mathrm{~m}$ ) during the day using single pass continual electrofishing (SEN battery-powered backpack electrofishing gear, Bednár, Czech Republic) fitted with a $2 \mathrm{~mm}$ mesh anode, with $100 \mathrm{~m}$ of shoreline generally being sampled. Details on the actual sampling methods used are described in more detail in Polačik et al. (2008). All fish sampled (native and non-native) were identified and measured, native species being immediately returned alive to the water. Fish data are presented as relative percentage and estimated total density $\left(\right.$ fish $\cdot \mathrm{m}^{-2}$ ) at each site (Table I).

All round gobies were sacrificed with an overdose of clove oil then placed in ice for transport to the laboratory. In the laboratory, the fish were measured to the nearest $0.01 \mathrm{~mm}$ using digital callipers, weighed to the nearest $0.01 \mathrm{~g}$ (total weight) and fin clips taken and stored in $96 \%$ ethanol for further genetic analysis. Sex was determined during fish dissection based on the type of gonads present and on external genitalia. Fish with absent or indistinguishable gonads were considered as juveniles and those with clearly distinguishable gonads as adults. The proportion of each sex (juveniles excluded) was used to calculate the adult sex-ratio.

\section{Table I}

Geographic characteristics (GPS coordinates and river $\mathrm{km}$ ) and fish assemblage structure (relative \%) for the four sites monitored on the upper Elbe on 26th August 2015.

\begin{tabular}{|c|c|c|c|c|c|}
\hline \multicolumn{2}{|l|}{ Site } & Dolní Žleb & Děčín & Svádov & Nučnice \\
\hline & 363 & 353 & 333 & 295 \\
\hline Coordinates $\mathbf{N}$ & & $50^{\circ} 50^{\prime} 33.14^{\prime \prime}$ & $50^{\circ} 46^{\prime} 53.66^{\prime \prime}$ & $50^{\circ} 39^{\prime} 57.27^{\prime \prime}$ & $50^{\circ} 30^{\prime} 23.66^{\prime \prime}$ \\
\hline Coordinates E & & $14^{\circ} 13^{\prime} 04.16^{\prime \prime}$ & $14^{\circ} 12^{\prime} 26.30^{\prime \prime}$ & $14^{\circ} 06^{\prime} 00.83^{\prime \prime}$ & $14^{\circ} 13^{\prime} 33.72^{\prime \prime}$ \\
\hline Common name & Scientific name & & & & \\
\hline Roach & Rutilus rutilus & 21.6 & 7.4 & 27.6 & 24.4 \\
\hline Dace & Leuciscus leuciscus & 1.1 & 5.5 & & \\
\hline Chub & Leuciscus cephalus & 55.7 & 25.2 & 17.2 & 45.3 \\
\hline Ide & Leuciscus idus & & 2.5 & 3.0 & 2.9 \\
\hline Nase & Chondrostoma nasus & 3.4 & 6.7 & & \\
\hline Gudgeon & Gobio gobio & & 4.9 & 10.4 & 12.2 \\
\hline White-fin & Gobio albipinnatus & 1.1 & 1.2 & 1.5 & \\
\hline gudgeon & & & & & \\
\hline Stone morocco & Pseudorasbora parva & & & 0.7 & \\
\hline Barbel & Barbus barbus & 13.6 & 21.5 & 17.9 & \\
\hline Bleak & Alburnus alburnus & & 2.5 & & 0.6 \\
\hline Vimba & Vimba vimba & & & & 4.7 \\
\hline Bitterling & Rhodeus amarus & & & & 8.1 \\
\hline Goldfish & Carassius auratus & & & & 0.6 \\
\hline Stone loach & Barbatula barbatula & & 1.8 & & \\
\hline Wells & Silurus glanis & & & & 0.6 \\
\hline $\begin{array}{l}\text { Three-spined } \\
\text { stickleback }\end{array}$ & $\begin{array}{c}\text { Gasterosteus } \\
\text { aculeatus }\end{array}$ & & & & \\
\hline Perch & Perca fluviatilis & 1.1 & 11.0 & 7.5 & 0.6 \\
\hline Ruffe & $\begin{array}{c}\text { Gymnocephalus } \\
\text { cernuus }\end{array}$ & 2.3 & 6.1 & 6.7 & \\
\hline European bullhead & Cottus gobio & & 0.6 & 0.7 & \\
\hline Round goby & $\begin{array}{c}\text { Neogobius } \\
\text { melanostomus }\end{array}$ & & 3.1 & 6.7 & \\
\hline \multicolumn{2}{|c|}{ Total density (fish. $\mathbf{m}^{-2}$ ) } & 44.0 & 81.5 & 167.5 & 172.0 \\
\hline
\end{tabular}




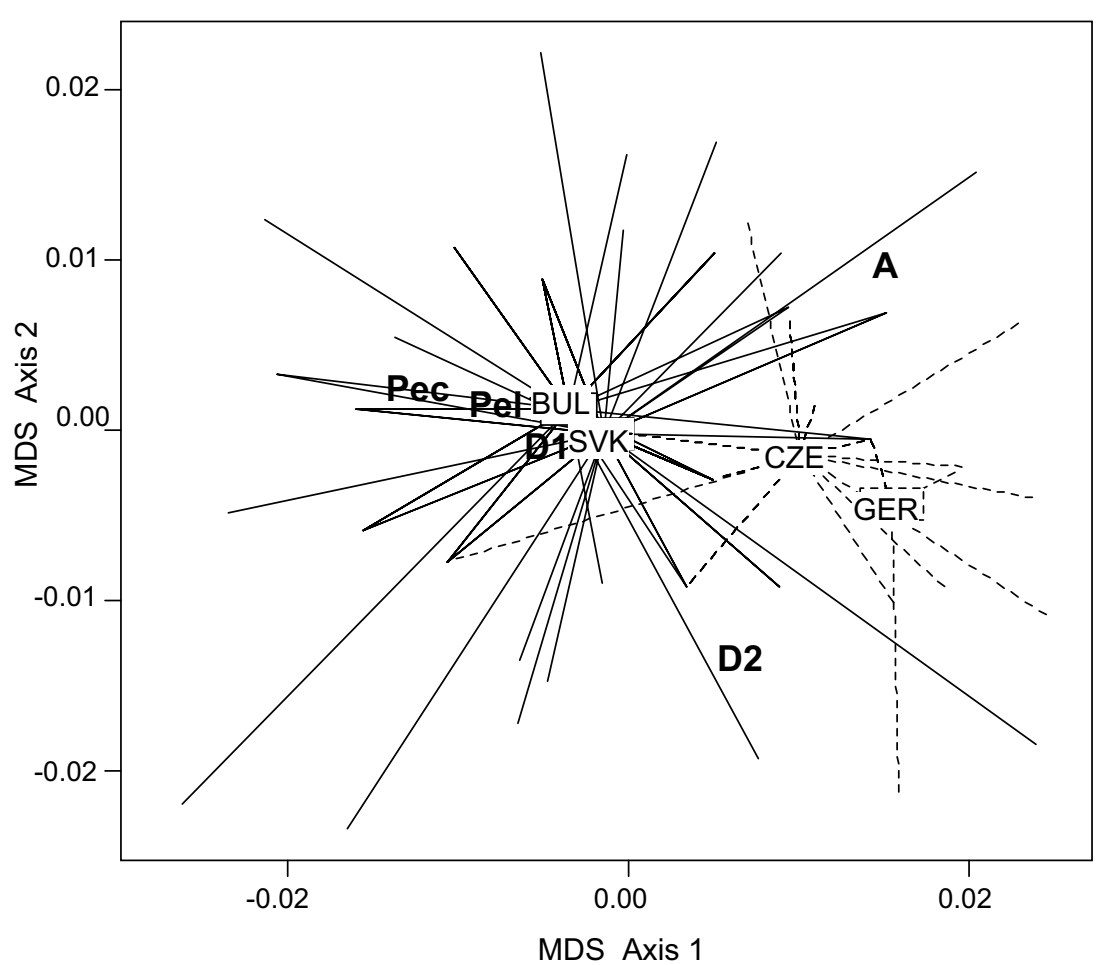

Figure 2

MDS ordination showing similarities in meristic characteristics (in bold) of four round goby populations. Number of fin rays: $P e c=$ pectoral, $P e l=$ pelvic, $D 1=1$ st dorsal, $D 2=2$ nd dorsal, $A=$ anal. Populations: $B U L=$ Bulgarian Danube, $S V K=$ Slovakian Danube, CZE = Czech Elbe, GER = German Elbe.

Morphological characteristics (data presented in Supplementary Table I) were compared with those originating from the tidal Elbe (data obtained from Hempel and Thiel, 2013) and nonnative and native Danubian populations from Slovakia and Bulgaria, respectively (described in Polačik et al., 2012). Only meristic characteristics were taken into account due to allometric growth in round gobies (L'avrinčíková et al., 2005) and a mismatch in fish length between populations. Multiple analysis of variance (MANOVA) and multidimensional scaling were used to compare and visualise the meristic characters, using the $\mathrm{R}$ statistical software, version 3.2.1 (R Core Team, 2015).

\section{RESULTS}

Round goby were present at both Svádov (r. km 333) and Děčín (r. km 353) but not at Dolní Žleb (r. km 363) or Nučnice (r. km 295) (see Figure 1; Table I). Fourteen fish were caught at Svádov (equivalent to 0.11 fish $\cdot \mathrm{m}^{-2}$ ) and five at Děćín (equivalent to $0.03 \mathrm{fish} \cdot \mathrm{m}^{-2}$ ). At both positive sites, native species were present in high abundance, with gobies representing a minor part of the assemblage (Table I).

All five gobies caught at Děčín were $<46 \mathrm{~mm}$ SL, presumably representing young-of-theyear fish. On the other hand, most gobies sampled at Svádov (13 ind.) had fully-developed gonads and were classed as adults. Most of these fish were between 40 and $65 \mathrm{~mm} \mathrm{SL}$, with one individual measuring $78 \mathrm{~mm} \mathrm{SL}$ and one $102 \mathrm{~mm} \mathrm{SL}$ (in the absence of further aging evidence (e.g. scale readings), we estimate that these correspond with $1+, 2+$ and $3+$ fish, respectively). The overall male:female sex ratio at Svádov was 1.83:1.

There was no significant difference in meristic characteristics between round gobies from the tidal Elbe and the upper Elbe (MANOVA, $P=0.24$; Figure 2). There was, however, a significant difference between both Elbe populations and the two Danubian populations (MANOVA, all $P<0.001 ;$ Figure 2). 


\section{DISCUSSION}

In this study, the detection of a newly established round goby population far from any source population provides compelling new evidence supporting the rapid spread of round gobies in European river networks through port-to-port transfer by shipping. Several lines of evidence strongly suggest that the upper Elbe population originated through boat-mediated transport from the port at Hamburg on the tidal Elbe.

Both the upper and lower Elbe populations share statistically similar morphological (meristic) characteristics. While such evidence could be considered indirect as a) meristic characteristics are not fully heritable (Hermida et al., 2002) and (b) morphological characteristics can change significantly due to environmental factors within just a few weeks (Olsson and Eklöv, 2005; Heerman et al., 2007), it is certainly compelling. The morphological analysis also discredits the possibility that the fish originated from within the Czech Republic through overland transport (e.g. in an anglers bait bucket) from the Rivers Morava and Dyje, until now the only established round goby population in the Republic. The Morava/Dyje population, which originated through natural migration up the Morava from the Danube, should share morphological characteristics with Danubian gobies, which in turn display distinct morphological differences to those on both the upper and lower Elbe. Moreover, despite being closer geographically $(290 \mathrm{~km})$, gobies have no possibility of migrating naturally between the Morava/Dyje and Elbe as they are situated in different watersheds, unconnected by any artificial canal.

Secondly, the rate of spread appears too fast for natural dispersal to have taken place (i.e. by swimming). As we are unaware of any further surveys reporting goby occurrence upstream of Geesthacht since the single observation in 2012, gobies would have to have swum $600 \mathrm{~km}$ upstream in just three years. This is far beyond the rate of natural upstream migration observed in recent studies (estimates range from 1-15 km per year; see Marentette et al., 2011; Lynch and Mensinger, 2012; Janáč et al., 2012).

Finally, the upper Elbe population appears to be restricted to the area immediately surrounding the inland port at Ústí nad Labem, which lies approximately $1.5 \mathrm{~km}$ upstream of Svádov. Our data suggest that gobies have not yet penetrated Střekov weir, $4 \mathrm{~km}$ upstream of the port (first weir on the Elbe upstream of Geesthacht), as no gobies were found at Nučnice. Furthermore, no gobies were caught $30 \mathrm{~km}$ downstream of the port at Dolní Žleb. The five fish found at Děčín (20 km downstream of the port) were all juveniles and, while it is possible that they represent new arrivals, it is more probable that they colonised the site as drifting early life-stages from the near-port stretch (see Janáč et al., 2013). Děčín, therefore, in addition to representing the furthest downstream extent of the population also provides evidence of reproduction and expansion from an upstream site. This same pattern of restricted distribution near ports has also been observed in other isolated round goby 'populations' (e.g. Vienna/Bratislava; Roche et al., 2013).

Thus far, the upper Elbe round goby population represents a minor part of the local fish assemblage (note, however that local fishermen have reported high densities around the port itself [not sampled during our survey]; T. Kava, pers. comm.). Based on previous experience, it is highly likely that gobies will come to dominate the local fish assemblage, as they have elsewhere (see Kornis et al., 2012). Furthermore, as drift of early life-stages has been shown to greatly increase the rate at which gobies spread downstream (Janáč et al., 2012), colonisation of the German stretch of the Elbe, with eventual connection with the downstream tidal population, would appear inevitable. Upstream migration is likely to be much slower, in part due to the presence of multiple weirs along this upper stretch.

Previous studies, and particularly those from the Laurentian Great Lakes, have reported round gobies directly affecting native fish assemblages through predation of eggs and juveniles (Chotkowski and Marsden, 1999; Roseman et al., 2006), competition for shelter and spawning interference (Janssen and Jude, 2001; Balshine et al., 2005; Bergstrom and Mensinger, 2009). To date, however, none of these has been confirmed as having a major impact in European rivers (Vašek et al., 2014; Všetičková et al., 2015; Janáč, unpublished data). Instead, we suspect that round gobies will affect the native fish assemblage through effects on other ecosystem components, e.g. by providing a reservoir for native parasites (i.e. the 
spill-back effect; Ondračková et al., 2015), strongly impacting local invertebrate communities (Lederer et al., 2008; Kipp and Ricciardi, 2012) and through incorporation into food-webs (Rush et al., 2012; Polačik et al., 2015), with subsequent alterations to food-web structure and energy and pollutant transfer (Rogers et al., 2014).

This newly established population highlights the speed with which this species has been able to colonise wide areas of Europe via establishment of widely-separated populations through port-to-port transfer and rapid inter-site connection through downstream drift and natural migration. Its recent establishment and presently isolated status provides an ideal opportunity for long-term monitoring in order to assess rates of colonisation and actual impacts on recipient ecosystems.

\section{ACKNOWLEDGEMENTS}

We would like to express our thanks to Ing. Tomaš Kava, manager of the North Bohemian Anglers Union, for alerting us to the presence of round goby on the Elbe, for enabling us to survey in their fishing grounds and for kind help in the field. We also thank Matej Polačik for providing data on Danubian goby morphometry. Finally, we thank two anonymous reviewers for their valuable comments on a previous version of the manuscript. This study was supported by the Grant Agency of the Czech Republic, Grant No. P505/11/1768.

\section{REFERENCES}

Ahnelt H., Banarescu P., Spolwind R., Harka A. and Waidbacher H., 1998. Occurrence and distribution of three gobiid species (Pisces, Gobiidae) in the middle and upper Danube region - examples of different dispersal patterns? Biologia, 53, 665-678.

Balshine S., Verma A., Chant V. and Theysmeyer T., 2005. Competitive interactions between round gobies and logperch. J. Gt. Lakes Res., 31, 68-77.

Bergstrom M.A. and Mensinger A.F., 2009. Interspecific resource competition between the invasive round goby and three native species: logperch, slimy sculpin, and spoonhead sculpin. Trans. Am. Fish. Soc., 138, 1009-1017.

Borcherding J., Staas S., Kruger S., Ondračková M., Šlapanský L. and Jurajda P., 2011. Non-native Gobiid species in the lower River Rhine (Germany): recent range extensions and densities. $J$. Appl. Ichthyol., 27, 153-155.

Brunken H., Castro J.F., Hein M., Verwold A. and Winkler M., 2012. First records of round goby Neogobius melanostomus (Pallas, 1814) in the river Weser. Lauterbornia, 75, 31-37.

Buřič M., Bláha M., Kouba A. and Drozd B., 2015. Upstream expansion of round goby (Neogobius melanostomus) - first record in the upper reaches of Elbe river. Knowl. Manag. Aquat. Ecosyst., 416, 32

Chotkowski M.A. and Marsden J.E., 1999. Round goby and mottled sculpin predation on lake trout eggs and fry: Field predictions from laboratory experiments. J. Gt. Lakes Res., 25, 26-35.

Grabowska J., Kotusz J. and Witkowski A, 2010. Alien invasive fish species in Polish waters: an overview. Folia Zool., 59, 73-85.

Hayden T.A. and Miner J.G., 2009. R apid dispersal and establishment of a benthic Ponto-Caspian goby in Lake Erie: diel vertical migration of early juvenile round goby. Biol. Invasions, 11, 1767-1776.

Heerman L., Beeck P. and Borcherding J., 2007. Two size classes of $0+$ perch: is phenotypic plasticity based on food resources? J. Fish Biol., 70, 1365-1377.

Hempel M. and Thiel R., 2013. First records of the round goby Neogobius melanostomus (Pallas, 1814) in the Elbe River, Germany. Biolnvasions Rec., 2, 291-295.

Hermida M., Fernandez C., Amaro R. and San Miguel E., 2002. Heritability and "evolvability" of meristic characters in a natural population of Gasterosteus aculeatus. Can. J. Zool., 80, 532-541.

Janáč M., Valová Z. and Jurajda P., 2012. Range expansion and habitat preferences of non-native 0+ tubenose goby (Proterorhinus semilunaris) in two lowland rivers in the Danube basin. Fundam. Appl. Limnol., 181, 73-85. 
Janáč M., Šlapanský L., Valová Z. and Jurajda P., 2013. Downstream drift of round goby (Neogobius melanostomus) and tubenose goby (Proterorhinus semilunaris) in their non-native area. Ecol. Freshw. Fish, 22, 430-438.

Janssen J. and Jude D.J., 2001. Recruitment failure of mottled sculpin Cottus bairdi in Calumet Harbor, southern Lake Michigan, induced by the newly introduced round goby Neogobius melanostomus. J. Gt. Lakes Res., 27, 319-328.

Jude D.J., Reider R.H. and Smith G.R., 1992. Establishment of Gobiidae in the Great-Lakes Basin. Can. J. Fish. Aq. Sci., 49, 416-421.

Jurajda P., Černý J., Polačik M., Valová Z., Janáč M., Blažek R. and Ondračková M., 2005. The recent distribution and abundance of non-native Neogobius fishes in the Slovak section of the River Danube. J. Appl. Ichthyol., 21, 319-323.

Jurajda P., Jurajdová Z., Roche K. and Šlapanský L. 2013. Survey of fish communities in the lower Czech Elbe. Report of the Institute of Vertebrate Biology, Academy of Sciences of the Czech Republic. (In Czech; Unpublished data)

Kalchhauser I., Mutzner P., Hirsch P.E. and Burkhardt-Holm P., 2013. Arrival of round goby Neogobius melanostomus (Pallas, 1814) and bighead goby Ponticola kessleri (Günther, 1861) in the High Rhine (Switzerland). Biolnvasions Rec., 2, 79-83.

Kipp R. and Ricciardi A., 2012. Impacts of the Eurasian round goby (Neogobius melanostomus) on benthic communities in the upper St. Lawrence River. Can. J. Fish. Aq. Sci., 69, 469-486.

Kornis M.S., Mercado-Silva N. and Vander Zanden M.J., 2012. Twenty years of invasion: a review of round goby Neogobius melanostomus biology, spread and ecological implications. J. Fish Biol., 80, 235-285.

L’avrinčíková M., Kováč, V. and Katina, S., 2005. Ontogenetic variability in external morphology of round goby Neogobius melanostomus from Middle Danube, Slovakia. J. Appl. Ichthyol., 21, 328-334.

Lederer A.M., Janssen J., Reed T. and Wolf A., 2008. Impacts of the Introduced round goby (Apollonia melanostoma) on dreissenids (Dreissena polymorpha and Dreissena bugensis) and on macroinvertebrate community between 2003 and 2006 in the littoral zone of Green Bay, Lake Michigan. J. Gt. Lakes Res., 34, 690-697.

Lynch M.P. and Mensinger A.F., 2012. Seasonal abundance and movement of the invasive round goby (Neogobius melanostomus) on rocky substrate in the Duluth-Superior Harbor of Lake Superior. Ecol. Freshw. Fish, 21, 64-74.

Marentette J.R., Wang G., Tong S., Sopinka N.M., Taves M.D., Koops, M.A. and Balshine S., 2011. Laboratory and field evidence of sex-biased movement in the invasive round goby. Behav. Ecol. Sociobiol., 65, 2239-2249.

Michalek M., Puntila R., Strake S. and Werner M., 2012. Abundance and distribution of round goby (Neogobius melanostomus). HELCOM Baltic Sea Environment Fact Sheets. http://www.helcom.fi/ baltic-sea-trends/environment-fact-sheets/.

Miller P.J., 2004. The Freshwater Fishes of Europe, Vol 8/II Gobiidae 2. Aula-Verlag, Wiesbaden. 478 p.

Olsson J. and Eklöv P., 2005. Habitat structure, feeding mode and morphological reversibility: factors influencing phenotypic plasticity in perch. Evol. Ecol. Res., 7, 1109-1123

Ondračková M., Hudcová I., Dávidová M., Adámek Z., Kašný M. and Jurajda P., 2015. Non-native gobies facilitate the transmission of Bucephalus polymorphus (Trematoda). Parasit. Vectors, 8, 382.

Painter S. and Seifert K., 2006. First record of the round goby, Neogobius melanostomus (Gobiidae), in the German Danube. Lauterbornia, 58, 101-107.

Polačik M., Janáč M., Jurajda P., Vassilev M. and Trichkova T., 2008. The sampling efficiency of electrofishing for Neogobius species in a riprap habitat: a field experiment. J. Appl. Ichthyol., 24, 601-604.

Polačik M., Janáč M., Vassilev M. and Trichkova T., 2012. Morphometric comparison of native and nonnative populations of round goby Neogobius melanostomus from the River Danube. Folia Zool., $61,1-8$.

Polačik M., Jurajda P., Blažek R. and Janáč M., 2015. Carcass feeding as a cryptic foraging mode in round goby Neogobius melanostomus. J. Fish Biol., 87, 194-199.

R Core Team, 2015. R: A language and environment for statistical computing. R Foundation for Statistical Computing, Vienna, Austria. http://www.R-project.org/. 
Ray W.J. and Corkum L.D., 2001. Habitat and site affinity of the round goby. J. Gt. Lakes Res., 27, 329-334.

Roche K.F., Janáč M. and Jurajda P., 2013. A review of Gobiid expansion along the Danube-Rhine corridor - geopolitical change as a driver for invasion. Knowl. Manag. Aquat. Ecosyst., 411, 01.

Rogers M.W., Bunnell D.B., Madenjian C.P. and Warner D.M., 2014. Lake Michigan offshore ecosystem structure and food web changes from 1987 to 2008. Can. J. Fish. Aq. Sci., 71, 1072-1086.

Roseman E.F., Taylor W.W., Hayes D.B., Jones A.L. and Francis J.T., 2006. Predation on walleye eggs by fish on reefs in western Lake Erie. J. Gt. Lakes Res., 32, 415-423.

Rush S.A., Paterson G., Johnson T.B., Drouillard K.G., Haffner G.D., Hebert C.E., Arts M.T., McGoldrick D.J., Backus S.M., Lantry B.F., Lantry J.R., Schaner T. and Fisk A.T., 2012. Long-term impacts of invasive species on a native top predator in a large lake system. Freshwater Biol., 57, 2342-2355.

Sapota, M.R. and Skora, K.E., 2005. Spread of alien (non-indigenous) fish species Neogobius melanostomus in the Gulf of Gdansk (south Baltic). Biol. Invasions, 7, 157-164.

Schomaker C. and Wolter C., 2014. First record of the round goby Neogobius melanostomus (Pallas, 1814) in the lower River Oder, Germany. Biolnvasions Rec., 3, 185-188.

Skóra K.E. and Stolarski J., 1993. New fish species in the Gulf of Gdañsk. Neogobius sp. [cf. Neogobius melanostomus (Pallas, 1811)]. Bull. Sea Fish. Inst., 1, 83-84.

van Beek G.C.W., 2006. The round goby Neogobius melanostomus first recorded in the Netherlands. Aquat. Inv., 1, 42-43.

Vašek M., Všetičková L., Roche K. and Jurajda P., 2014. Diet of two invading gobiid species (Proterorhinus semilunaris and Neogobius melanostomus) during the breeding and hatching season: No field evidence of extensive predation on fish eggs and fry. Limnologica, 46, 31-36.

Vsetičková L., Janáč M., Roche K. and Jurajda P., 2015. Assessment of possible diel and sex-related differences in round goby (Neogobius melanostomus) diet. Folia Zool., 64, 104-111.

Wiesner C., 2005. New records of non-indigenous gobies (Neogobius spp.) in the Austrian Danube. J. Appl. Ichthyol., 21, 324-327.

Cite this article as: K. Roche, M. Janáč, L. Šlapanský, L. Mikl, L. Kopeček, and P. Jurajda, 2015. A newly established round goby (Neogobius melanostomus) population in the upper stretch of the river Elbe. Knowl. Manag. Aquat. Ecosyst., 416, 33. 


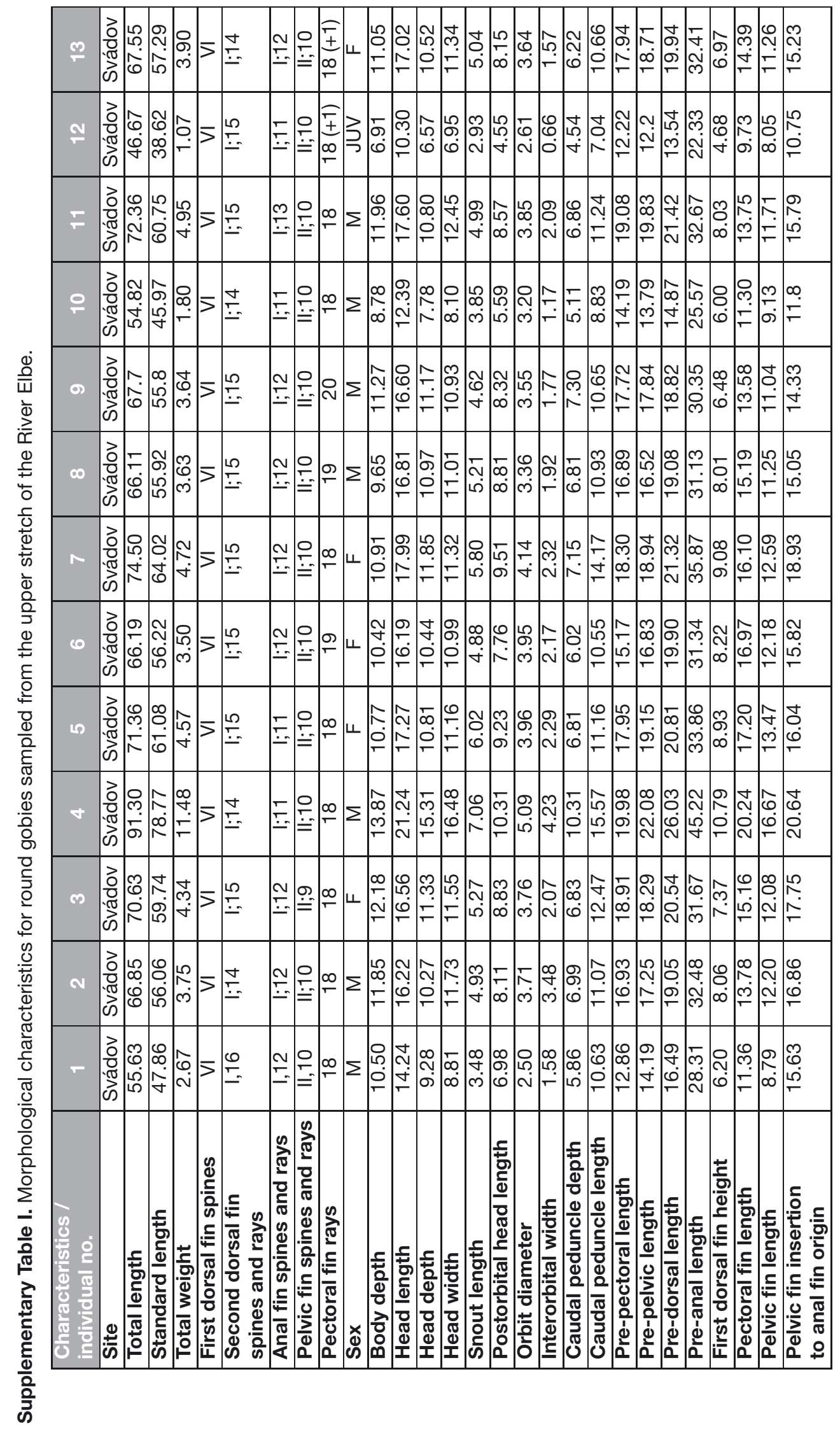




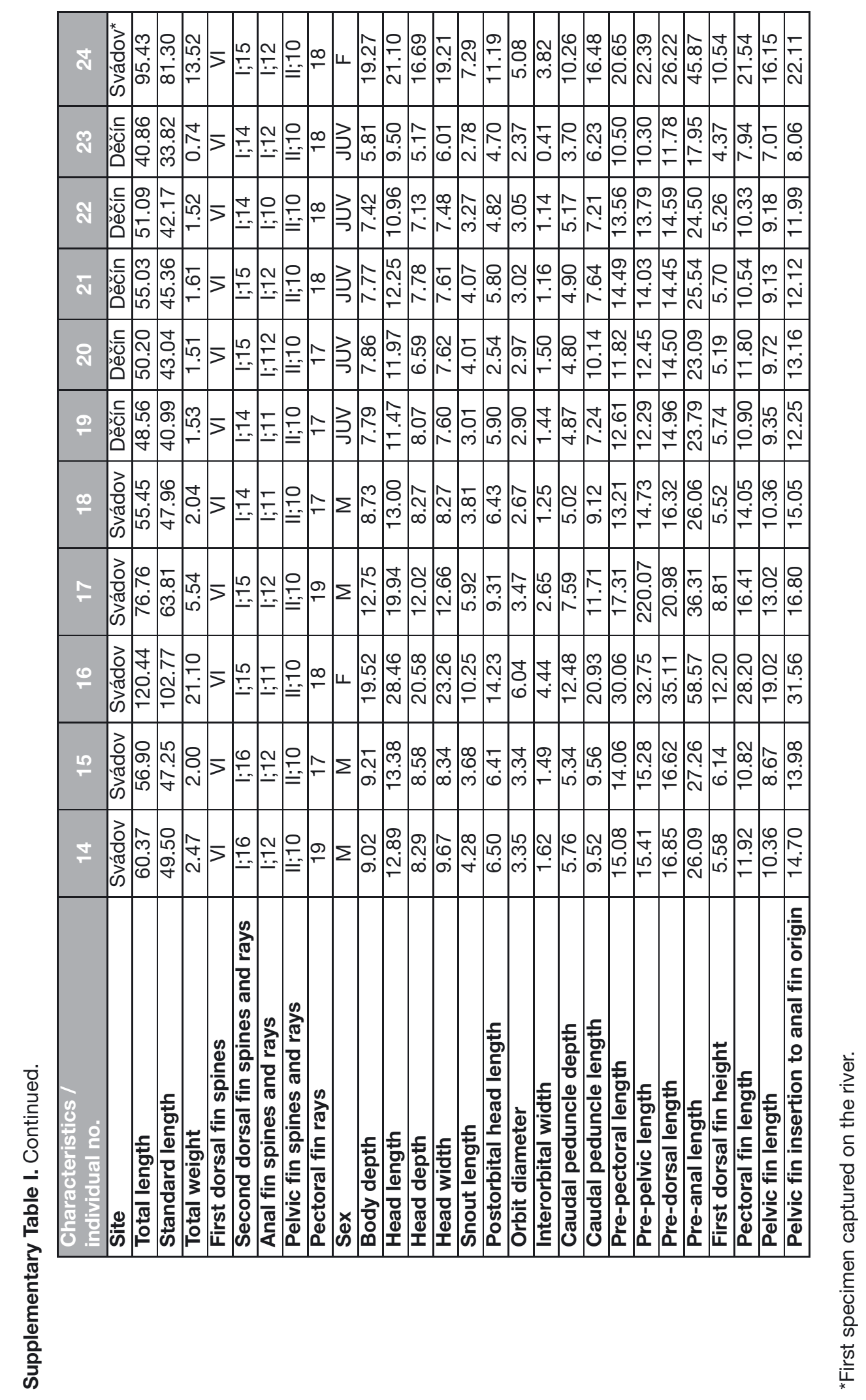

